\title{
ANALISIS KONTRIBUSI PENDAPATAN PETANI PADI SAWAH DI KABUPATEN BARITO SELATAN
}

\author{
Lina Trisnawati ${ }^{1}$, Betrixia Barbara ${ }^{2}$, Trisna Anggreini ${ }^{2}$
}

\begin{abstract}
This research aim to analysis knowing contribution of rice farming income to total income of farmer household of paddy rice in Regency of South Barito. The result is the percentage of the main income contribution is the work as a rubber farmer is the work that has the greatest contribution to the total income of households of rice farmers in South Barito regency of $78.88 \%$. While the income of households from rice farming is the income that has the lowest contribution that is $8.12 \%$ to total household income, because in this regency majority of society's main job is to become rubber farmer, while for farmer farmer of paddy rice field, farmer only work it only subsistence does not give priority to increase household income.
\end{abstract}

Keywords : Analysis contribution Income, farmer, Rice Farm Household Economy

\section{PENDAHULUAN}

\subsection{Latar Belakang}

Dalam rangka mewujudkan kemandirian, kedaulatan dan ketahanan pangan nasional, salah satu program prioritas pemerintah adalah mewujudkan swasembada padi, jagung dan kedelai. Kementerian Pertanian telah menetapkan upaya khusus peningkatan produksi padi, jagung dan kedelai yang keberhasilannya antara lain sangat ditentukan oleh kinerja dari upaya penambahan luas baku lahan sawah, rehabilitasi jaringan irigasi, penyediaan alat dan mesin pertanian, penyediaaan dan penggunaan benih unggul, penyediaan dan penggunaan pupuk, Kebijakan dan Regulasi termasuk pengaturan terkait Harga Pembelian Pemerintah (HPP) dan pembelian hasil panen raya (stabilisasi harga) oleh pemerintah sebagai buffer stock, dan peningkatan kinerja penyuluh pertanian di daerah yang berpotensi sebagai penyedia pangan nasional, serta sistem penyimpanan hasil panen. Upaya khusus pencapaian swasembada padi, jagung, dan kedelai dapat dilihat pada Gambar 1 . di bawah ini. 


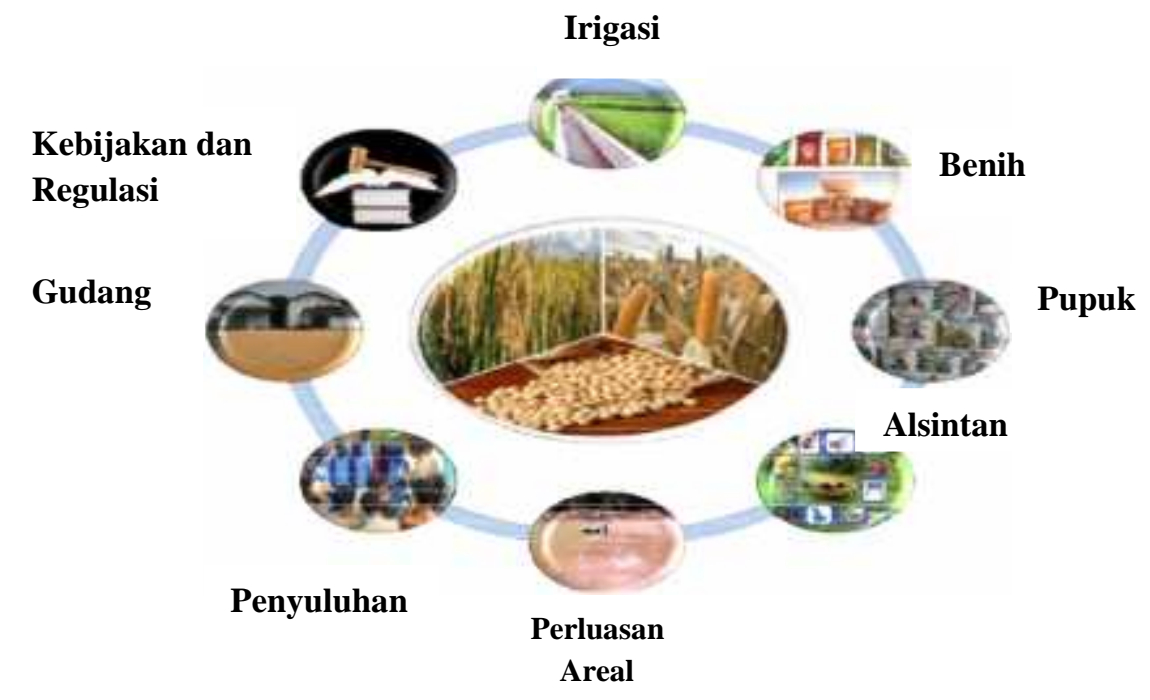

Gambar 1. Upaya Khusus Pencapaian Swasembada Padi, Jagung, dan Kedelai

Sumber : Kementerian Pertanian Republik Indonesia, 2015

Luas lahan menurut penggunaan (Badan Pusat Statistik, 2014) mengungkapkan bahwa luas lahan sawah di Kalimantan Tengah selama Tahun 2008-2015 terus mengalami peningkatan, sehingga produksi padi sawah juga senantiasa mengalami peningkatan. Penambahan lahan sawah merupakan salah satu bentuk capaian Kementerian Pertanian dalam rangka peningkatan produksi tanaman pangan melalui program pencetakan lahan sawah baru dan optimalisasi lahan sawah. Adapun luas panen, produksi, dan produktivitas padi sawah di Kalimantan Tengah selama delapan tahun terakhir terlihat pada Grafik di bawah ini.

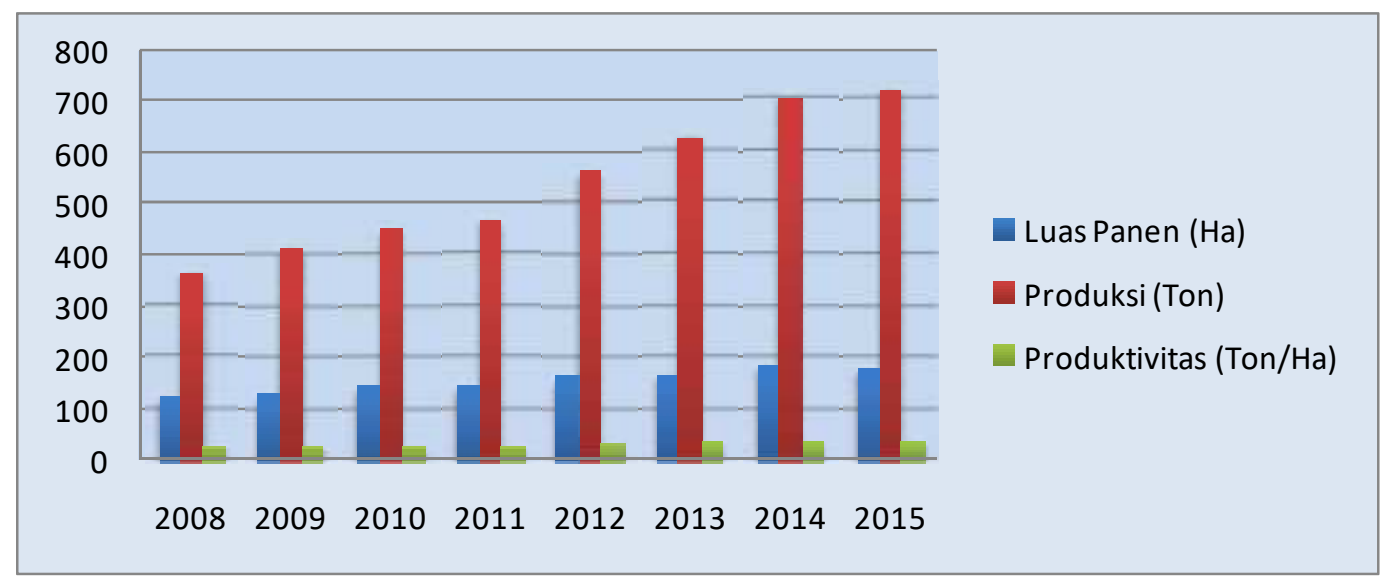

Gambar 2 Luas Panen, Produksi, dan Produktivitas Padi Sawah di Kalimantan Tengah, Tahun 2008-2015

Sumber : Badan Pusat Statistik Provinsi Kalimantan Tengah, 2016 
Salah satu daerah di Kalimantan Tengah yang potensial untuk program perluasan areal persawahan adalah Kabupaten Barito Selatan. Adapun luas panen, produksi, dan produktivitas padi sawah di Kabupaten Barito Selatan selama delapan tahun terakhir seperti pada Tabel 1.

Tabel 1. Luas Panen, Produksi, dan Produktivitas Padi Sawah di Kabupaten Barito Selatan, Tahun 2008-2015

\begin{tabular}{crrr}
\hline Tahun & Luas Panen (Ha) & Produksi (Ton) & Produktivitas (Ton/Ha) \\
\hline 2008 & 5.739 & 16.130 & 2,81 \\
2009 & 5.308 & 13.425 & 2,52 \\
2010 & 3.690 & 10.002 & 2,71 \\
2011 & 4.764 & 13.320 & 2,79 \\
2012 & 6.269 & 18.612 & 2,96 \\
2013 & 3.708 & 12.324 & 3,32 \\
2014 & 5.631 & 18.975 & 3,37 \\
2015 & 5.667 & 19.964 & 3,52 \\
\hline
\end{tabular}

Sumber : Badan Pusat Statistik Kabupaten Barito Selatan, 2016.

Berdasarkan Tabel 1. terlihat bahwa produksi padi sawah berdasarkan data di Kabupaten Barito Selatan setiap tahunnya berfluktuasi, dari Tahun 2008 produksi padi sawah terus menurun hingga Tahun 2010. Penurunan produksi tersebut disebabkan karena penurunan luas panen yang disebabkan perubahan fungsi lahan pertanian ke perkebunan kelapa sawit. Tahun 2011 dan Tahun 2012 produksi padi sawah kembali mengalami peningkatan ini terbukti dengan meningkatnya luas panen dan produktivitasnya, tetapi pada Tahun 2013 produksi padi sawah kembali mengalami penurunan produksi yang juga disebabkan karena terjadinya puso yang diakibatkan oleh terjadinya banjir dan serangan hama penyakit, terjadinya puso tersebut akan berpengaruh terhadap penurunan luas panen dan produksi padi sawah. Sedangkan pada Tahun 2014 dan Tahun 2015 produksi padi sawah kembali mengalami peningkatan ini dikarena adanya program Kalteng Besuh oleh Gubernur Kalimantan Tengah Tahun 2013.

\begin{tabular}{lllr}
\multicolumn{2}{c}{ Berdasarkan } & \multicolumn{2}{r}{ lokasi } \\
penyebaran & padi sawah di \\
Kalimantan & Tengah & Kabupaten
\end{tabular} Barito Selatan menempati urutan ke enam untuk luas panen dan produksi padi sawah, sedangkan untuk produktivitasnya berada pada urutan ke 10. Hal ini menunjukkan penggunaan input pada produksi padi sawah masih belum efisien, sedangkan berdasarkan hasil Sensus Tanaman 2013 (ST2013) diketahui bahwa rumahtangga pangan di Kabupaten Barito Selatan didominasi oleh rumahtangga yang mengelola tanaman padi. Jenis padi sawah lebih banyak diusahakan oleh rumahtangga di Kabupaten Barito Selatan. Berdasarkan hal tersebut Kabupaten Barito Selatan memiliki potensi untuk pengembangan 
produksi dan usahatani padi sawah (Badan Pusat Statistik Kabupaten Barito Selatan, 2014).

Permasalahan yang dihadapi ditingkat petani dalam upaya peningkatan produksi padi sawah sampai saat ini antara lain masih rendahnya penggunaan benih padi unggul bermutu yang disebabkan rendahnya daya beli petani akibat terbatasnya kemampuan ekonomi, disamping itu terbatasnya pengetahuan dan wawasan para petani terhadap manfaat penggunaan benih padi unggul bermutu sehingga jumlah produksi dan mutu hasil dari padi mereka masih rendah. Selain itu, permasalahan lain yang dihadapi adalah petani kesulitan untuk memprediksi cuaca atau musim yang tepat untuk menanam, jika terlalu cepat menanam, padi akan diserbu hama tikus. Sebaliknya, kalau terlambat, akan berpengaruh karena faktor alam. Peningkatan produksi pertanian diharapkan mampu meningkatkan pendapatan bagi petani. Pendapatan usahatani padi sawah di Kabupaten ini masih rendah, dimana masih tidak memberikan kontribusi untuk pendapatan rumahtangganya, yang menyebabkan tingkat perekonomian petani masih rendah.

\subsection{Tujuan Penelitian}

Penelitian ini mempunyai tujuan untuk mengetahui kontribusi pendapatan usahatani padi sawah terhadap total pendapatan rumahtangga petani padi sawah di Kabupaten Barito Selatan

\section{METODE PENELITIAN}

\subsection{Tempat dan Waktu Penelitian}

Penelitian ini dilaksanakan di Kabupaten Barito Selatan. Pemilihan lokasi penelitian ini ditentukan secara sengaja (purposive) karena Kabupaten Barito Selatan merupakan salah satu daerah di Kalimantan Tengah yang masuk dalam program perluasan areal persawahan, dan juga berdasarkan hasil Sensus Tanaman 2013 (ST2013) diketahui bahwa rumahtangga pangan di Kabupaten Barito Selatan didominasi oleh rumahtangga yang mengelola tanaman padi. Jenis padi sawah lebih banyak diusahakan oleh rumahtangga di Kabupaten Barito Selatan.

Penelitian ini dilaksanakan selama 1 (satu) tahun yaitu dari bulan September 2016 sampai bulan September 2017. Kegiatan yang dilaksanakan meliputi penyusunan proposal penelitian, pengumpulan data sekunder, pengumpulan data primer di lapangan, pengolahan dan analisis data, sampai dengan ujian skripsi.

\subsection{Jenis dan Sumber Data}

Jenis dan sumber data yang digunakan dalam penelitian ini adalah data primer dan sekunder.

1. Data primer diperoleh melalui survei lapangan dan wawancara terhadap para petani dan Penyuluh Lapangan di Kabupaten Barito Selatan.

2. Data sekunder diperoleh dari BPS (Badan Pusat Statistik) Provinsi Kalimantan Tengah, dan Dinas Pertanian dan Perkebunan Kabupaten Barito Selatan, UPTBBPP Kecamatan Gunung Bintang Awai, UPTB-BPP Kecamatan Dusun Hilir, UPTB-BPP Kecamatan Karau Kuala, UPTB- 
BPP Kecamatan Jenamas, dan UPTB-BPP Kecamatan Dusun Selatan.

\subsection{Pengambilan dan Penentuan Sampel}

Penentuan besarnya sampel penelitian ini mengambil sampel sebanyak 60 sampel, yaitu terdiri dari 30 sampel di Kecamatan Dusun Selatan, dan 30 sampel di Kecamatan Gunung Bintang Awai. Pengambilan sampel ini dengan pertimbangan dari enam Kecamatan di Kabupaten Barito Selatan, Kecamatan Dusun Selatan merupakan Kecamatan yang memproduksi padi sawah tertinggi dan sebagai sentra padi di Barito Selatan dan juga Kecamatan Dusun Selatan memiliki musim tanam pada bulan April-September (ASEP), sedangkan untuk Kecamatan
Gunung Bintang Awai produksi padi sawahnya masih rendah dan memiliki musim tanam pada bulan Oktober-Maret (OKMAR).

\subsection{Analisis Data}

Analisis data adalah bagian terpenting dalam metode penelitian, data dalam penelitian dianalisis baik sebelum peneliti memasuki lapangan, selama berada di lapangan, dan tentunya setelah semua informasi berhasil dihimpun. Analisis data disesuaikan dengan tujuan penelitian, guna menjawab tujuan penelitian.

Analisis untuk menjawab tujuan ketiga mengetahui kontribusi pendapatan usahatani padi sawah terhadap total pendapatan rumahatangga petani padi sawah di Kabupaten Barito Selatan adalah sebagai berikut :

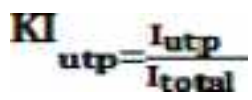

\section{$\times 100 \%$}

Keterangan : $\mathrm{KI}_{\text {utp }} \quad=$ Kontribusi (\%) pendapatan usahatani padi sawah terhadap pendapatan total rumahtangga

$\mathrm{I}_{\mathrm{utp}} \quad=$ Pendapatan usahatani padi sawah (Rp/musim tanam)

$\mathrm{I}_{\text {total }} \quad=$ Pendapatan total rumahtangga (pendapatan usahatani padi sawah, pendapatan utama, dan pendapatan sampingan)

\section{HASIL DAN PEMBAHASAN}

\subsection{Karakteristik Responden}

Responden dalam penelitian ini merupakan petani padi sawah di Kabupaten Barito Selatan. Karakteristik responden adalah identitas petani responden yang terdiri dari jenis kelamin, umur petani, pendidikan formal, jumlah tanggungan, jenis pekerjaan utama dan pekerjaan sampingan, luas lahan garapan, status kepemilikan lahan, dan tingkat produksi padi sawah.

\section{Jenis Kelamin Petani Responden}

Jenis kelamin merupakan suatu indikator yang dapat menunjukkan produktivitas petani dalam bekerja. Jika dilihat dari kemampuan bekerja, rata-rata laki-laki lebih kuat dan alokasi waktu untuk usahatani lebih banyak dibandingkan alokasi waktu waktu perempuan dikarenakan kegiatan perempuan tidak hanya 
mengerjakan usahatani tetapi juga dibebani mengurus rumah tangga. Adapun karakteristik petani responden berdasarkan jenis kelamin dapat dilihat pada Tabel 2. di bawah ini.

\section{Tabel 2. Karakteristik Responden Berdasarkan Jenis Kelamin}

\begin{tabular}{lrrr}
\hline \multirow{2}{*}{ Jenis Kelamin } & \multicolumn{3}{c}{ Jumlah Responden } \\
\cline { 2 - 4 } & Orang & \multicolumn{2}{c}{ Persentase (\%) } \\
\hline Laki-laki & 34 & 56,67 \\
Perempuan & 26 & 43,33 \\
\hline Jumlah & 60 & 100 \\
\hline
\end{tabular}

Sumber : Data Primer yang diolah, Tahun 2017

Berdasarkan hasil penelitian yang diperoleh dilapangan dari 60 petani responden, petani responden yang terpilih lebih dominan berjenis kelamin laki-laki. Dimana dari 60 petani responden, petani responden berjenis kelamin laki-laki sebanyak 34 orang $(56,67 \%)$ dan petani responden berjenis kelamin perempuan sebanyak 26 orang $(43,33 \%)$.

\section{Umur Petani Petani Responden}

Menurut Badan Pusat Statistik usia produktif adalah pada usia 15-64 tahun, dimana pada usia 15-49 tahun digolongkan pada usia sangat produktif, dan pada usia 50-64 tahun merupakan usia produktif. Umur sangat berpengaruh terhadap produktivitas tenaga kerja. Berdasarkan hasil penelitian umur petani responden yang mengelola padi sawah adalah berkisar antara 26 tahun sampai dengan 70 tahun. Adapun karakteristik petani responden berdasarkan umur dapat dilihat pada Tabel 3. di bawah ini.

\section{Tabel 3. Karakteristik Responden Berdasarkan Umur}

\begin{tabular}{crr}
\hline \multirow{2}{*}{ Umur (Tahun) } & \multicolumn{3}{c}{ Jumlah Responden } \\
\cline { 2 - 4 } & Orang & \multicolumn{1}{c}{ Persentase (\%) } \\
\hline $26-49$ & 37 & 61,66 \\
$50-64$ & 19 & 31,67 \\
$65-70$ & 4 & 6,67 \\
\hline Jumlah & 60 & 100 \\
\hline
\end{tabular}

Sumber : Data Primer yang diolah, Tahun 2017

Berdasarkan tabel di atas dari 60 petani responden, rata-rata petani padi sawah berada pada usia produktif, dimana usia sangat produktif lebih dominan yaitu sebanyak 37 orang $(61,66 \%)$. Sedangkan petani responden yang digolongkan pada usia tidak produktif hanya 4 orang $(6,67 \%)$.

Kondisi umur petani terkait dengan produktivitas tenaga kerja dalam berusahatani, bahwa hampir seluruh aktivitas usahatani berhubungan dengan tingkat 
kemampuan fisik. Petani responden pada usia produktif tentu memiliki tingkat produktivitas yang tinggi dibandingkan dengan petani yang memiliki usia tidak produktif. Umur petani juga terkait dengan proses adopsi inovasi dan transfer teknologi, dimana petani dengan usia muda cenderung lebih progresif dalam proses adopsi inovasi dan transfer inovasi baru.

\section{Pendidikan Formal Petani Responden}

Tabel 4. Karakteristik Responden Berdasarkan Pendidikan Formal

\begin{tabular}{crr}
\hline \multirow{2}{*}{ Pendidikan Terakhir } & \multicolumn{3}{c}{ Jumlah Responden } \\
\cline { 2 - 4 } & Orang & Persentase (\%) \\
\hline SD & 11 & 18,33 \\
SMP & 19 & 31,67 \\
SMA & 26 & 43,33 \\
Perguruan Tinggi & 4 & 6,67 \\
\hline Jumlah & 60 & 100 \\
\hline
\end{tabular}

Sumber : Data Primer yang diolah, Tahun 2017

Berdasarkan hasil penelitian petani responden rata-rata pernah menempuh pendidikan formal, di mana dari 60 responden, responden dengan pendidikan terakhir SMA merupakan yang paling dominan yaitu sebanyak 26 orang $(43,33 \%)$.

\section{Jumlah Tanggungan Keluarga Petani Responden}

Tanggungan merupakan salah satu faktor yang berpengaruh dalam mengelola usahatani, karena jumlah tanggungan yang dimiliki petani responden akan mendorong petani lebih giat bekerja dalam berusaha untuk meningkatkan pendapatan agar dapat memenuhi kebutuhan keluarga. Jumlah tanggungan keluarga
Pendidikan petani responden merupakan pendidikan formal terakhir yang pernah ditempuh petani. Tingkat pendidikan merupakan salah satu indikator untuk mengukur produktivitas kerja seseorang. Tingkat pendidikan sangat terkait dengan tingkat kemampuan mengadopsi inovasi teknologi dalam usahatani. Adapun karakteristik petani responden berdasarkan pendidikan formal dapat dilihat pada Tabel 4. di bawah ini. 
Tabel 5. Karakteristik Responden Berdasarkan Jumlah Tanggungan Keluarga

\begin{tabular}{crr}
\hline Jumlah Tanggungan & \multicolumn{3}{c}{ Jumlah Responden } \\
\cline { 2 - 4 } Keluarga (Orang) & Orang & Persentase (\%) \\
\hline $1-2$ & 10 & 16,66 \\
$3-4$ & 36 & 60 \\
$5-6$ & 13 & 21,67 \\
$\geq 7$ & 1 & 1,67 \\
\hline Jumlah & 60 & 100 \\
\hline
\end{tabular}

Sumber : Data Primer yang diolah, Tahun 2017

Berdasarkan hasil penelitian, dari 60 petani responden jumlah tanggungan sebanyak 3-4 orang lebih dominan yaitu sebanyak 36 orang (60\%), sedangkan jumlah tanggungan yang paling sedikit adalah 7 orang yaitu sebanyak 1 orang $(1,67 \%)$.

\section{Karakteristik \\ Berdasarkan Jenis Pekerjaan Petani Responden}

Berdasarkan hasil penelitian dari 60 responden, yang merupakan jenis pekerjaan yang paling utama dikerjakan oleh petani responden merupakan petani karet dan sebagian kecil yang memiliki pekerjaan utama diluar petani karet seperti rotan, warung, dan buruh. Selain itu ada sebagian kecil responden yang memiliki pekerjaan utama diluar usaha pertanian sebagai PNS, guru, PPL, honorer, dan karyawan batu bara. Sedangkan untuk pekerjaan sampingan petani adalah mengelola padi sawah, peternakan, hortikultura, perikanan, kehutanan dan juga buruh dibidang pertanian maupun diluar pertanian.

\section{Luas dan Status Kepemilikan Lahan Garapan Petani Responden}

Lahan merupakan faktor produksi terpenting dalam usahatani, Adiwilaga (1982) dalam Muzdalifah (2011) menyatakan bahwa sukses usahatani tergantung dari bentangan tanah usahanya sehingga luas lahan tanah garapan menjadi sangat penting untuk meningkatkan suatu produksi usahatani. Luas lahan garapan petani responden untuk usahatani padi sawah beragam. Luas lahan tersempit adalah 0,04 ha sedangkan luas lahan yang paling luas adalah 1,5 ha, rata-rata luas lahan yang digarap petani adalah 0,41 ha. Adapun luas lahan garapan dapat dilihat pada Tabel 6 .

Tabel 6. Karakteristik Responden Berdasarkan Luas Lahan Garapan

\begin{tabular}{|c|c|c|c|}
\hline No & Luas Lahan (Ha) & Jumlah Responden & Persentase (\%) \\
\hline 1 & $0,04-0,08$ & 11 & 18,33 \\
\hline 2 & $0,1-0,17$ & 12 & 20 \\
\hline 3 & $0,2-0,35$ & 14 & 23,34 \\
\hline 4 & $0,4-0,75$ & 11 & 18,33 \\
\hline 5 & $1-1,5$ & 12 & 20 \\
\hline \multicolumn{2}{|r|}{ Jumlah } & 60 & 100 \\
\hline
\end{tabular}

Sumber : Data primer yang diolah, Tahun 2017 
Lahan petani yang digunakan dalam proses produksi bisa merupakan lahan milik sendiri, sewa, gadai atau sakap yang masingmasing mempunyai ketentuan sesuai dengan fungsi kepemilikannya. Di Kabupaten Barito Selatan, status kepemilikan lahan petani lebih banyak milik sendiri, selain itu ada juga status kepemilikan lahan sakap atau lebih tepat lahan yang dipinjam. Untuk lahan yang disakap ketentuan sistem bagi hasilnya adalah dalam setiap $100 \mathrm{~m}^{2} \quad(1$ borongan), produksi padi sawah sebanyak $10 \mathrm{~kg}$ (1 blek) dalam bentuk Gabah Kering
Giling (GKG) diberikan untuk pemilik tanah. Tetapi pada kenyataannya dari 60 responden yang diwawancara tidak ada satupun yang benar-benar menerapkan ketentuan bagi hasil tersebut. Salah satu alasan kenapa ketentuan tersebut tidak diterapkan adalah dengan alasan bahwa lahan yang dipakai merupakan lahan milik keluarga sendiri, dan si pemilik tanah kebanyakan tidak menuntut bagi hasil dari tanahnya tersebut. Adapun status kepemilikan lahan dapat dilihat pada Tabel 7.

\section{Tabel 7. Karakteristik Responden Berdasarkan Status Kepemilikan Lahan}

\begin{tabular}{clrr}
\hline No. & Status Kepemilikan Lahan & Jumlah Responden & Persentase $(\%)$ \\
\hline 1 & Milik Sendiri & 38 & 63,33 \\
2 & Sakap & 23 & 38,33 \\
\hline \multicolumn{2}{c}{ Jumlah } & 61 & 101,66 \\
\hline
\end{tabular}

Sumber : Data Primer yang diolah, Tahun 2017

Berdasarkan Tabel 7 , ratarata responden mengusahakan lahan sawah milik sendiri yaitu sebanyak 38 responden $(63,33 \%)$, sedangkan yang mengerjakan lahan sawah milik orang lain (sakap) yaitu sebanyak 23 responden $(38,33 \%)$. Jika dilihat pada tabel diatas jumlah responden ada sebanyak 61 dan persentase sebesar $101,66 \%$, hal tersebut terjadi karena ada satu responden yang mengerjakan lahan sawah milik sendiri sekaligus juga mengerjakan lahan sawah milik orang lain, alasannya adalah pada saat melakukan penanaman pada lahan milik sendiri tanaman padi sawahnya diserang banjir sebanyak 3 kali yang menyebabkan padi sawahnya rusak, karena hal itu yang mendorong responden tersebut mengerjakan lahan sawah milik orang lain yang letaknya tidak terserang banjir tujuannya untuk menambah jumlah produksi padi yang dihasilkan.

\section{Karakteristik Responden Berdasarkan Tingkat Produksi Padi Sawah}

Produksi dapat diartikansebagai kegiatan optimalisasi dari faktorfaktor produksi seperti, tenaga kerja, modal, dan lain-lainnya oleh petani untuk mendapatkan hasil berupa padi sawah. Adapun produksi padi sawah di Kabupaten Barito Selatan dapat dilihat pada Tabel 8. 
Tabel 8. Karakteristik Responden Berdasarkan Tingkat Produksi Padi Sawah

\begin{tabular}{crr}
\hline Produksi Padi Sawah & \multicolumn{3}{c}{ Jumlah Responden } \\
\cline { 2 - 4 }$(\mathrm{Kw})$ & Orang & Persentase (\%) \\
\hline $1,2-1,5$ & 6 & 10 \\
$2-2,8$ & 3 & 5 \\
$3-3,2$ & 9 & 15 \\
$4-4,5$ & 6 & 10 \\
$5-5,25$ & 10 & 16,67 \\
$6-6,48$ & 6 & 10 \\
$7-7,6$ & 3 & 5 \\
$8-10$ & 5 & 8,33 \\
$12-15$ & 6 & 10 \\
$20-30$ & 6 & 10 \\
\hline Jumlah & 60 & 100 \\
\hline
\end{tabular}

Sumber : Data Primer yang diolah, Tahun 2017

Berdasarkan Tabel 8, produksi padi sawah di Kabupaten Barito Selatan dengan persentase 16,67 persen yaitu rata-rata sebesar 5-5,25 Kw. Berdasarkan hasil wawancara, produksi padi sawah di Kabupaten ini masih berada di bawah rata-rata produksi nasional. Hal ini disebabkan, budidaya padi sawah di Kabupaten Barito Selatan masih bersifat tradisional, dimana masih belum adanya menggunakan benih unggul bermutu, belum adanya pemupukan, dan pemeliharaan yang masih kurang. Hasil produksi hanya bergantung pada keadaan alam, sedangkan pada saat musim tanam padi sawah sering diserang banjir. Hal inilah yang menyebabkan produksi padi sawah di Kabupaten Barito Selatan masih rendah.

Kontribusi (\%) Pendapatan Usahatani Padi Swah Terhadap Total Pendapatan Rumah Tangga Petani Padi Sawah di Kabupaten Barito Selatan

\begin{abstract}
Selain pekerjaan utama yang menghasilkan pendapatan rumahtangga petani, petani juga mencari usaha sampingan untuk meningkatkan pendapatan rumahtangganya. Dengan demikian petani tidak mengalami ketergantungan dari pendapatan utama saja. Pekerjaan utama dan sampingan petani dihitung dalam satu kali musim tanam padi sawah yaitu selama \pm 10 bulan. Pekerjaan utama petani responden adalah sebagian besar bekerja sebagai petani karet, rotan, jualan, honorer, PNS. Sedangkan pekerjaan sampingan petani responden seperti menanam padi sawah, budidaya ikan, perikanan tangkap, buruh, tukang bangunan, budidaya nenas, dan peternakan. Adapun sumber pendapatan dan kontribusi pendapatan terhadap total pendapatan rumahtangga petani padi sawah di Kabupaten Barito Selatan dapat dilihat pada Tabel 9. di bawah ini.
\end{abstract}


Tabel 9. Kontribusi Pendapatan Usahatani Padi Swah Terhadap Total Pendapatan Rumah Tangga Petani Padi Sawah

\begin{tabular}{clr}
\hline No. & \multicolumn{1}{c}{ Uraian } & Jumlah \\
\hline 1 & Pendapatan Utama (Rp) & 29.34 .233 \\
2 & Pendapatan Sampingan (Rp) & 5.046 .250 \\
3 & Pendapatan Usahatani Padi Sawah (Rp) & 3.041 .198 \\
4 & Total Pendapatan Rumah tangga Petani (Rp) & 37.204 .091 \\
\hline 5 & Kontribusi Pendapatan Utama (\%) & 78,39 \\
6 & Kontribusi Pendapatan Sampingan (\%) & 13,48 \\
7 & Kontribusi Pendapatan Usahatani Padi Sawah (\%) & 8,12 \\
\hline \multirow{2}{*}{8} & Total Kontribusi Pendapatan Petani Terhadap & 100,00 \\
& Pendapatan Rumah tangga Petani (\%)
\end{tabular}

Sumber : Data Primer yang diolah, 2017

Berdasarkan Tabel 9. persentase kontribusi pendapatan utama yaitu pekerjaan sebagai petani karet merupakan pekerjaan yang memiliki kontribusi yang paling besar terhadap total pendapatan rumahtangga petani padi sawah di Kabupaten Barito Selatan yaitu sebesar 78,88\%. Sedangkan pendapatan rumahtangga yang berasal dari usahatani padi sawah merupakan pendapatan yang memiliki kontribusi yang paling rendah yaitu $8,12 \%$ terhadap total pendapatan rumahtangga, dikarena di Kabupaten ini mayoritas pekerjaan utama masyarakat adalah menjadi petani karet, sedangkan untuk usahatani petani padi sawah, petani hanya mengusahakannya hanya bersifat subsisten tidak mengutamakan untuk menambah pendapatan rumahtangga.

\section{KESIMPULAN DAN SARAN}

\subsection{Kesimpulan}

Berdasarkan tujuan yang telah dibuat pada penelitian ini, maka kesimpulan dari penelitian ini adalah sebagai berikut : Kontribusi pendapatan petani yang berasal dari usahatani padi sawah yaitu sebesar $8,12 \%$ terhadap total pendapatan rumahtangga, dikarena di Kabupaten ini mayoritas pekerjaan utama masyarakat adalah menjadi petani karet, sedangkan untuk usahatani petani padi sawah, petani hanya mengusahakannya bersifat subsisten tidak mengutamakan untuk menambah pendapatan rumahtangga.

\subsection{Saran}

1. Kepada petani :

a. Diharapkan dalam mengelola usahatani padi sawahnya tidak lagi bersifat subsisten, tetapi mengusahakannya kearah agribisnis, sehingga perekonomian petani bisa ditingkatkan.

b. Agar para petani bisa memanfaatkan bantuan yang diberikan oleh pemerintah seperti peralatan dan benih unggul.

2. Kepada pemerintah Kabupaten Barito yaitu Dinas Pertanian, terutama penyuluh pertanian :

a. Agar lebih aktif lagi dalam membimbing dan melakukan 
penyuluhan terutama masalah merubah budaya petani (pola pikir petani) agar lebih mudah menerima dan menerapkan teknologi sesuai anjuran contohnya dalam hal pengunaan pupuk dan pestisida.

b. Perlu adanya pemantauan dan pembimbingan terkait bantuan sarana produksi yang diberikan agar bantuan yang diberikan efektif dan berguna untuk petani, dan juga tujuan kebijakan pemerintah berjalan dengan baik.

3. Kepada kalangan akademis ataupun peneliti selanjutnya diharapkan dapat melakukan penelitian padi sawah kearah agribisnis.

\section{DAFTAR PUSTAKA}

Badan Pusat Statistik. 2014. Sensus Pertanian 2013, Hasil Pencacahan Lengkap. BPS Provinsi Kalimantan Tengah. CV Bima Media Mandiri.

Badan Pusat Statistik. 2014. Potret Usahatani Pertanian Barito Selatan Menurut Sub Sektor (Hasil Pencacahan Lengkap Sensus Pertanian 2013 dan Survei Pendapatan Rumah Tangga Usaha Pertanian 2013). BPS Kabupaten Barito Selatan, Buntok-Barsel.

Badan Pusat Statistik. 2016. Barito Selatan dalam Angka 2016. BPS Kabupaten Barito Selatan, Buntok-Barsel.
Dinas Pertanian dan Peternakan Provinsi Kalimantan Tengah, 2015. Perkembangan Statistik Tanaman Pangan Provinsi Kalimantan Tengah 20082014.

Direktorat Jenderal Prasarana dan Sarana Pertanian 2016. Pedoman Teknis Perluasan Sawah Pola Swakelola Tahun 2016. Jakarta.

Dominick, S. 1995. Teori dan Soal-soal Mikroekonomi. Edisi Kedua. Pene Erlangga. Jakarta.

Hanafie, R. 2010. Pengantar Ekonomi Pertanian. CV ANDI OFFSET (Penerbit Andi). Yogyakarta.

Mosher, AT. 1997. Menggerakkan dan Membangun Pertanian. Jakarta: CV. Yasaguna.

Mubyarto. 1989. Pengantar Ekonomi Pertanian. Jakarta: LP3S.

Pindyck, R.S., \& Rubinfeld, D.L. 2007. Mikroekonomi. Jilid I. Edisi Keenam. Terjemahan: Dewi, N.K. PT. INDEKS. Jakarta

Rahim, A dan Hastuti D. 2007. Ekonomika Pertanian (Pengantar, teori dan kasus). Penebar Swadaya. Jakarta.

Soekartawi. 1990. Teori Ekonomi Produksi dengan Pokok Bahasan Analisis Fungsi 
Cobb-Douglas. Jakarta, Rajawali Press.

Soekartawi. 1995. Analisis Usahatani. UI-Press. Jakarta.

Sudarsono, S. 1984. Pengantar Ekonomi Mikro. Modul 1-5, Universitas Terbuka. Jakarta.
Sukirno, S. 2000. Ekonomi Makro. Raja Grapindo Persada, Jakarta.

Tanaman Pangan dan Hortikultura, BPS Deptan 1993. 